\title{
The effect of interaction between macromolecule supplement and oxygen tension on bovine oocytes and embryos cultured in vitro
}

\author{
G.Z. Mingoti ${ }^{1}$, V.S.D. Caiado Castro ${ }^{2}$, S.C. Méo ${ }^{3}$, L.S.S. Barretto ${ }^{2}$ and J.M. Garcia ${ }^{2}$
}

School of Veterinary Medicine, Department of Animal Health, UNESP, Araçatuba; School of Agricultural and Veterinary Sciences, Department of Preventive Veterinary Medicine and Animal Reproduction, UNESP, Jaboticabal; and Cattle-Southeast, Brazilian Agricultural Research Corporation, EMBRAPA, São Carlos, SP, Brazil.

Date submitted: 15.10.2008. Date accepted: 24.02.2009

\section{Summary}

\begin{abstract}
Aiming to improve in vitro production of bovine embryos and to obtain supplements to replace serum for in vitro maturation (IVM), this study evaluated the effects of macromolecular supplementation of IMV medium (bovine serum albumin - BSA, polyvinyl alcohol - PVA, polyvinyl pyrrolidone - PVP, Ficoll, KnockoutSR, or fetal calf serum - FCS) and oxygen tension $\left[5 \% \mathrm{CO}_{2}\right.$ in air $\left(20 \% \mathrm{O}_{2}\right)$ or $5 \% \mathrm{CO}_{2}$, $5 \% \mathrm{O}_{2}$ and $90 \% \mathrm{~N}_{2}\left(5 \% \mathrm{O}_{2}\right)$ ] on oocyte maturation and embryo development. Nuclear progression to germinal vesicle breakdown, metaphase I and metaphase II stages were evaluated and overall results revealed that undefined (FCS) and semi-defined (BSA) media gave better results at $20 \% \mathrm{O}_{2}$ and defined media (PVA, PVP and Ficoll) at 5\% $\mathrm{O}_{2}$. Independent of macromolecule supplement, IVM at $20 \% \mathrm{O}_{2}$ was considered optimal for nuclear maturation. To evaluate embryo development, oocytes matured in the previously described conditions were fertilized and cultured at the same oxygen tension used for IVM and assessed for cleavage ( 43.0 to $74.8 \%$ ) and development to morulae (16.4 to 33.8\%), blastocyst (7.7 to $52.9 \%$ ) and hatched blastocyst (9.6 to $48.1 \%$ ). Apart from oxygen tension, all treatments, except Knockout $(22.7 \%)$, gave similar results for blastocyst development (26.5 to $38.7 \%)$. Independently of macromolecule supplement, higher development rates were obtained in an oxygen tension of $20 \% \mathrm{O}_{2}(67.4 \%$ cleavage, $29.2 \%$ morulae, $40.8 \%$ blastocyst and $34.0 \%$ hatched blastocyst) when compared with $5 \% \mathrm{O}_{2}(52.5,21.8$, 18.2 and $15.6 \%$, respectively). This study indicates that BSA, PVA, PVP and Ficoll can replace serum during IVM and that the optimal atmospheric condition for in vitro production of bovine embryos is $5 \%$ $\mathrm{CO}_{2}$ and $20 \% \mathrm{O}_{2}$.
\end{abstract}

Keywords: Cattle, Embryo, Macromolecule, Maturation, Oocyte, Oxygen

\section{Introduction}

The in vitro culture systems used for embryo production still do not reach the level of effectiveness obtained in vivo. Whilst in vivo embryonic development rates achieve $70 \%$ blastocyst rate, only about $85 \%$ of

\footnotetext{
${ }^{1}$ All correspondence to: G.Z. Mingoti. School of Veterinary Medicine, Department of Animal Health, UNESP, Rua Clóvis Pestana, 793, 16050-680, Araçatuba, São Paulo, Brazil. Tel: +55 183636 1375; Fax: +55 183622 8451; e-mail: gmingoti@fmva.unesp.br

${ }^{2}$ School of Agricultural and Veterinary Sciences, Department of Preventive Veterinary Medicine and Animal Reproduction, UNESP, 14884-900, Jaboticabal, SP, Brazil.

${ }^{3}$ Cattle-Southeast, Brazilian Agricultural Research Corporation, EMBRAPA, 13560-970, São Carlos, SP, Brazil.
}

in vitro matured oocytes are fertilized and only 30 to $40 \%$ of these develop to the blastocyst stage (GutiérrezAdan et al., 2001). For this reason, the development of strategies to improve efficiency of in vitro production (IVP) of bovine embryos is sought. Among several factors associated with culture media and methods that influence this procedure, great importance is given to macromolecule supplements and atmospheric conditions.

The macromolecule supplements that are frequently employed in IVP are bovine serum albumin (BSA) and fetal calf serum (FCS). These supplements are colloid particles that facilitate fluid transport through biological membranes (Webster, 1982) and improve maturation and embryo development (Carolan et al., 1995). BSA and FCS quelate heavy metal ions, buffer $\mathrm{pH}$ and act as surfactants and reactive oxygen species 
(ROS) scavengers (Orsi \& Leese, 2004; Stein, 2007). BSA also increases intracellular free amino acids after its hydrolysis (Orsi \& Leese, 2004) and serum possesses more than 1000 different compounds, including growth factors and hormones (Stein, 2007). Because of those characteristics, it is difficult to obtain a suitable substitute for BSA and FCS in culture. However, as BSA and FCS are products of animal origin: (i) their composition is not completely known; (ii) they present high variation among producers and batches (Mckiernan \& Bavister, 1992); and (iii) they offer the risk of disease transmission (Krisher et al., 1999). Then the culture medium supplemented with BSA and FCS is semi-defined or undefined in composition and contributes to variability of the culture systems and the obtained results (Bavister, 1995; Krisher et al., 1999).

Thus, aiming to standardize IVP procedures and also to avoid pathogens transmission, synthetic and defined supplement sources are frequently used, including polyvinyl alcohol (PVA; Fukui et al., 2000), polyvinyl pyrrolidone (PVP; Chung et al., 2007), Ficoll (Kuleshova et al., 1999) and serum replacers, as synthetic serum substitute (Sagirkaya et al., 2007) and KnockoutSR (Moore et al., 2007). Among them, PVA and PVP are the synthetic macromolecules most used in culture medium to replace BSA and FCS. Ficoll is a polysaccharide usually employed in vitrification solutions (Checura \& Seidel, 2007). KnockoutSR is a protein source used for stem-cell culture and whose defined formula is protected by fabricant, but does not have serum in its composition (Goldsborough et al., 1998). However, the embryos produced in fully defined media usually present a developmental block (Camous et al., 1984) and reduced viability (Wright \& Bondioli, 1981) when compared with those embryos cultured in undefined or semi-defined media.

Atmospheric conditions also affect IVP because the oxygen tension usually employed in in vitro culture (5\% $\mathrm{CO}_{2}$ in air, which corresponds to $20 \% \mathrm{O}_{2}$ ) is higher than that existent in ovarian follicles, oviduct and uterus. In follicles, the oxygen from capillaries diffuses through the layers of granulosa cells and a gradient of $\mathrm{O}_{2}$ occurs from the follicle periphery to the central oocyte (Gosden \& Byatt-Smith, 1986). Early embryo development after fertilization begins in oviduct, where the $\mathrm{O}_{2}$ tension is lower than in the atmosphere (Mass et al., 1976). Thus, the higher oxygen concentration used for in vitro culture may be a factor in the production of ROS that provoke intracellular damage and are detrimental for embryonic development (Batt et al., 1991). However, the published results using $20 \%$ or $5 \% \mathrm{O}_{2}$ during the IVP steps are still controversial. Some research in bovine demonstrates that culture in lower oxygen tension (from 5 to $10 \%$ ) improves maturation and embryo development (Nakao \&
Nakatsuji, 1990; Thompson et al., 1990; Voelkel \& Hu, 1992) whilst others observed better results when using 20\% $\mathrm{O}_{2}$ (Oyamada \& Fukui, 2004; Castro e Paula \& Hansen, 2007). Moreover, evidences of interaction between culture medium and oxygen tension were also reported (Noda et al., 1994; Castro e Paula \& Hansen, 2007).

Among the steps in IVP, in vitro maturation (IVM) is highlighted (Brackett \& Zuelke, 1993; Eppig, 1996; Sirard \& Blondin, 1996) because in this phase the oocyte accumulates the mRNA and proteins that are essential to progression to the embryonic genome activation stage and to the acquisition of developmental competence (Thibault et al., 1987; Sirard et al., 1989).

Thus, the aim of this study was to evaluate the effects of macromolecule supplements (BSA, PVA, PVP, Ficoll, Knockout and FCS) in IVM and of oxygen tension of $5 \%$ or $20 \%$ during all IVP procedures (maturation, fertilization and development culture - IVMFC) on oocyte nuclear maturation and embryo development to hatched blastocyst stage.

\section{Materials and methods}

\section{Reagents, media and culture conditions}

Chemicals were purchased from Sigma Chemical Co., unless otherwise stated.

The medium for in vitro maturation (IVM) consisted of TCM-199 (Gibco BRL) supplemented with $0.2 \mathrm{mM}$ sodium pyruvate, $25 \mathrm{mM}$ sodium bicarbonate, 75 $\mu \mathrm{g} / \mathrm{ml}$ kanamycin (Gibco BRL), $0.5 \mu \mathrm{g} / \mathrm{ml}$ FSH (Pluset ${ }^{\circledR}$ ), $\left.100 \mathrm{IU} / \mathrm{ml} \mathrm{hCG} \mathrm{(Profasi}{ }^{\circledR}\right), 1.0 \mu \mathrm{g} / \mathrm{ml}$ estradiol and one macromolecular supplement according to experimental design.

In vitro fertilization (IVF) medium consisted of Tyrode's albumin lactate pyruvate (TALP) supplemented with $0.2 \mathrm{mM}$ sodium pyruvate, $6 \mathrm{mg} / \mathrm{ml}$ fatty acidfree BSA, $25 \mathrm{mM}$ sodium bicarbonate, $13 \mathrm{mM}$ sodium lactate, $75 \mu \mathrm{g} / \mathrm{ml}$ kanamycin, $4 \mu \mathrm{l} / \mathrm{ml}$ PHE solution ( $2 \mathrm{mM}$ penicillamine, $1 \mathrm{mM}$ hypotaurine and $250 \mu \mathrm{M}$ epinephrine) and $10 \mu \mathrm{g} / \mathrm{ml}$ heparin.

In vitro culture (IVC) medium was synthetic oviductal fluid (SOF) supplemented with $0.2 \mathrm{mM}$ L-glutamine, $0.34 \mathrm{mM}$ sodium citrate, $2.8 \mathrm{mM}$ myoinositol, 2\% MEM essential amino acid solution, $1 \%$ MEM non-essential amino acid solution, $0.2 \mathrm{mM}$ sodium pyruvate, $75 \mu \mathrm{g} / \mathrm{ml}$ kanamycin, $5 \mathrm{mg} / \mathrm{ml}$ fraction V fatty acid-free BSA and $2.5 \%$ FCS.

Cultures (IVM, IVF and IVC) were carried out at $38.5^{\circ} \mathrm{C}$ with maximum humidity and under an atmosphere of $5 \% \mathrm{CO}_{2}$ in air $\left(20 \% \mathrm{O}_{2}\right)$ or $5 \% \mathrm{CO}_{2}, 5 \% \mathrm{O}_{2}$ and $90 \% \mathrm{~N}_{2}\left(5 \% \mathrm{O}_{2}\right)$ depending upon the experimental design. 


\section{Oocyte recovery and culture}

Abattoir-derived ovaries were transported to the laboratory in saline solution at $30-35^{\circ} \mathrm{C}$. The follicles (2-8 $\mathrm{mm}$ ) were aspirated using an 18-gauge needle attached to a $20 \mathrm{ml}$ syringe. Oocytes with at least four layers of cumulus cells were selected for the experiments.

For IVM, oocytes were washed and cultured in IVM medium supplemented with $6 \mathrm{mg} / \mathrm{ml} \mathrm{BSA}, 6 \mathrm{mg} / \mathrm{ml}$ PVA, 6 mg/ml PVP, 6 mg/ml Ficoll, 10\% KnockoutSR (Gibco BRL), or 10\% FCS (Gibco BRL). The IVM culture was performed in $100 \mu \mathrm{l}$ droplets (20 oocytes per droplet) under mineral oil (Dow Corning Co.) for $24 \mathrm{~h}$.

\section{Assessment of nuclear maturation}

The percentage of oocytes at germinal vesicle breakdown (GVBD), metaphase I (MI) and metaphase II (MII) stages were respectively recorded at 6, 18 and $24 \mathrm{~h}$ of IVM. For that purpose, oocytes were stripped from their cumulus cells by vortexing for $3 \mathrm{~min}$ in $0.2 \%$ hyaluronidase and then stained with $10 \mu \mathrm{g} / \mathrm{ml}$ Hoechst 33342 for $10 \mathrm{~min}$, placed between slide and coverslip and visualized under epifluorescence microscopy (330$385 \mathrm{~nm}$; at $200 \times$ magnification).

\section{In vitro fertilization}

Motile spermatozoa were obtained by centrifugation of frozen-thawed semen on a Percoll (Pharmacia) discontinuous density gradient (2 $\mathrm{ml}$ of $45 \%$ Percoll over $2 \mathrm{ml}$ of $90 \%$ Percoll) for $30 \mathrm{~min}$ at $900 \mathrm{~g}$ at room temperature. The supernatant was discarded and the spermatozoa were counted on a haemocytometer and then resuspended in IVF medium to obtain a final concentration of $2 \times 10^{6}$ cells $/ \mathrm{ml}$. Finally, $4 \mu \mathrm{l}$ of the sperm suspension were added to each droplet, for a final concentration of $1 \times 10^{6}$ sperm $/ \mathrm{ml}$. Oocytes and sperm were co-incubated for $24 \mathrm{~h}$.

\section{In vitro development culture and embryo evaluation}

Following fertilization, the presumptive zygotes were transferred to IVC medium. Zygotes were incubated under mineral oil up to $48 \mathrm{~h}$ for assessment of cleavage rates under stereoscopic microscopy (at a $40 \times$ magnification), when 2- and 4-cell embryos were counted. Morulae, blastocyst and hatched blastocyst development rates were observed, respectively, at 144 (day 6), 168 (day 7) and $192 \mathrm{~h}$ (day 8) post insemination (hpi).

\section{Experimental design}

Experiment I: The effects of macromolecular supplementation of IVM medium and oxygen tension on oocyte nuclear maturation

Oocytes ( $n=4129$ in five replicates) were in vitro matured in medium supplemented with one of the following macromolecules: BSA (6 $\mathrm{mg} / \mathrm{ml})$, PVA $(6 \mathrm{mg} / \mathrm{ml})$, PVP $(6 \mathrm{mg} / \mathrm{ml})$, Ficoll $(6 \mathrm{mg} / \mathrm{ml})$, Knockout (10\%), or FCS (10\%); in two oxygen tension: $5 \% \mathrm{CO}_{2}$ in air $\left(20 \% \mathrm{O}_{2}\right)$ and $5 \% \mathrm{CO}_{2}, 5 \% \mathrm{O}_{2}$ and $90 \% \mathrm{~N}_{2}\left(5 \% \mathrm{O}_{2}\right)$. Oocytes were assessed for nuclear maturation and data for GVBD, MI and MII were collected, respectively, at 6,18 and 24 h of IVM.

Experiment II: The effects of macromolecular supplementation of IVM medium and oxygen tension during maturation, fertilization and culture on embryonic development

Oocytes ( $n=1139$ in six replicates) were in vitro matured for $24 \mathrm{~h}$ in the same conditions described for the Experiment I. After IVM, they were submitted to IVF and IVC in $20 \%$ or $5 \% \mathrm{O}_{2}$ and data for cleavage (48 hpi) and development to morulae (144 hpi), blastocyst (168 hpi) and hatched blastocyst (192 hpi) were calculated over total number of oocytes, and were recorded.

\section{Statistical analysis}

In this study, data were reported as mean \pm standard error (SEM). Data were arcsine transformed and analysed by ANOVA in which the effect of macromolecule, oxygen tension and interaction between macromolecule and oxygen tension were evaluated. When a statistical significant effect was found, multiple comparisons of means were determined using Tukey's test (SAS Program V.8). A $p$-value $<0.05$ was considered to be statistically significant.

\section{Results}

\section{Experiment I: The effects of macromolecular supplementation of IVM medium and oxygen tension on oocyte nuclear maturation}

At $6 \mathrm{~h}$ of IVM in $20 \%$ oxygen tension, GVBD rates in oocytes treated with FCS $(49.8 \% \pm 4.9)$ were higher $(p<0.05)$ than in PVP $(30.7 \% \pm 5.3)$, Ficoll $(32.0 \% \pm$ 5.1) and Knockout (31.1\% \pm 4.9$)$ (Table 1). At 5\% $\mathrm{O}_{2}$, the treatments PVA $(43.0 \% \pm 5.7), \operatorname{PVP}(44.7 \% \pm 5.9)$ and Ficoll $(43.8 \% \pm 7.6)$ were superior $(p<0.05)$ to BSA $(25.2 \% \pm 4.3)$, Knockout $(22.3 \% \pm 4.9)$ and FCS $(24.1 \%$ \pm 4.8 ) (Table 1). For all treatments, except BSA and FCS that presented higher $(p<0.05)$ results at $20 \% \mathrm{O}_{2}$, the 
Table 1 Oocyte nuclear maturation stages.

\begin{tabular}{|c|c|c|c|c|c|c|c|}
\hline \multirow[b]{2}{*}{$\mathrm{O}_{2}$ tension $(\%)$} & \multirow[b]{2}{*}{ Group } & \multicolumn{2}{|c|}{ GVBD (6 h) } & \multicolumn{2}{|r|}{ MI (18 h) } & \multicolumn{2}{|r|}{ MII (24 h) } \\
\hline & & $n$ & $\%$ mean \pm SEM & $n$ & $\%$ mean \pm SEM & $n$ & $\%$ mean $\pm S E M$ \\
\hline \multirow[t]{6}{*}{20} & BSA & 81 & $40.3 \pm 5.6^{a, b}$ & 104 & $38.4 \pm 5.6^{c}$ & 95 & $64.9 \pm 6.2^{a}$ \\
\hline & PVA & 79 & $35.5 \pm 8.6^{a-c}$ & 104 & $41.4 \pm 5.8^{b, c}$ & 136 & $67.6 \pm 5.5^{a}$ \\
\hline & PVP & 83 & $30.7 \pm 5.3^{b, c}$ & 125 & $34.6 \pm 6.5^{c}$ & 117 & $62.5 \pm 5.2^{a}$ \\
\hline & Ficoll & 130 & $32.0 \pm 5.1^{b, c}$ & 123 & $32.0 \pm 6.5^{c}$ & 137 & $60.6 \pm 6.4^{a}$ \\
\hline & Knockout & 101 & $31.1 \pm 4.9^{b, c}$ & 121 & $32.9 \pm 6.0^{c}$ & 135 & $54.4 \pm 6.3^{a-c}$ \\
\hline & FCS & 118 & $49.8 \pm 4.9^{a}$ & 86 & $36.4 \pm 5.2^{c}$ & 99 & $60.0 \pm 5.8^{a}$ \\
\hline \multirow[t]{6}{*}{5} & BSA & 86 & $25.2 \pm 4.3^{c}$ & 76 & $35.0 \pm 6.1^{c}$ & 116 & $36.8 \pm 5.9^{d}$ \\
\hline & PVA & 104 & $43.0 \pm 5.7^{a, b}$ & 129 & $58.5 \pm 6.8^{a, b}$ & 111 & $41.9 \pm 6.4^{b-d}$ \\
\hline & PVP & 116 & $44.7 \pm 5.9^{a, b}$ & 98 & $66.1 \pm 5.6^{a}$ & 115 & $56.0 \pm 5.2^{a, b}$ \\
\hline & Ficoll & 106 & $43.8 \pm 7.6^{a, b}$ & 103 & $60.4 \pm 5.9^{a}$ & 152 & $38.5 \pm 5.7^{c, d}$ \\
\hline & Knockout & 125 & $22.3 \pm 4.9^{c}$ & 141 & $63.6 \pm 7.2^{a}$ & 149 & $29.3 \pm 6.1^{d}$ \\
\hline & FCS & 118 & $24.1 \pm 4.8^{c}$ & 144 & $50.5 \pm 7.2^{a-c}$ & 166 & $30.1 \pm 6.8^{d}$ \\
\hline
\end{tabular}

Germinal vesicle breakdown (GVBD), metaphase I (MI) and metaphase II (MII), respectively, at 6, 18 and 24 h of in vitro maturation in medium supplemented with bovine serum albumin (BSA; $6 \mathrm{mg} / \mathrm{ml})$, polyvinyl alcohol (PVA; $6 \mathrm{mg} / \mathrm{ml}$ ), polyvinyl pyrrolidone (PVP; $6 \mathrm{mg} / \mathrm{ml})$, Ficoll $(6 \mathrm{mg} / \mathrm{ml})$, KnockoutSR $(10 \%)$ and fetal calf serum (FCS; 10\%), in oxygen $\left(\mathrm{O}_{2}\right)$ tensions of $5 \% \mathrm{CO}_{2}$ in $\operatorname{air}\left(20 \% \mathrm{O}_{2}\right)$ and $5 \% \mathrm{O}_{2}, 5 \% \mathrm{CO}_{2}$ and $90 \% \mathrm{~N}_{2}\left(5 \% \mathrm{O}_{2}\right)$.

${ }^{a-d}$ Values with different superscript letters within the same column differ $(p<0.05)$.

GVBD stage rates were similar $(p>0.05)$ between both oxygen tensions (Table 1 ).

At $18 \mathrm{~h}$, MI rates (32.0 to $41.4 \%)$ were similar $(p>$ 0.05 ) in all treatments at $20 \% \mathrm{O}_{2}$ (Table 1 ). In $5 \%$ oxygen tension, higher $(p<0.05) \mathrm{M}$ I rates were observed in groups PVA $(58.5 \% \pm 6.8)$, PVP $(66.1 \% \pm 5.6)$, Ficoll $(60.4 \% \pm 5.9)$, Knockout (63.6\% \pm 7.2$)$ and FCS (50.5\% \pm 7.2) (Table 1). The treatments PVP, Ficoll and Knockout presented differences $(p<0.05)$ between both oxygen tensions, and showed higher $(p<0.05)$ results at $5 \% \mathrm{O}_{2}$ (Table 1).

At $24 \mathrm{~h}$, similar $(p>0.05)$ MII rates (54.4 to $67.6 \%$ ) were observed among all treatments at $20 \% \mathrm{O}_{2}$ (Table 1). At $5 \% \mathrm{O}_{2}, \operatorname{PVP}(56.0 \% \pm 5.2)$ was superior $(p<0.05)$ to all treatments, but similar $(p>0.05)$ to PVA $(41.9 \pm 6.4)$ (Table 1$)$. PVP at $5 \% \mathrm{O}_{2}$ was similar $(p>0.05)$ to all treatments at $20 \% \mathrm{O}_{2}$. In a comparison of both oxygen tensions, PVP was the only treatment that showed similar $(p>0.05)$ MII rates at $20 \%$ and $5 \% \mathrm{O}_{2}$, while the other supplements presented better results at $20 \% \mathrm{O}_{2}$ (Table 1 ).

\section{Experiment II: The effects of macromolecular supplementation of IVM medium and oxygen tension during maturation, fertilization and culture on embryonic development}

Data for cleavage and embryonic development to morulae, blastocyst and hatched blastocyst after in vitro maturation in medium with different macromolecule supplements (BSA, PVA, PVP, Ficoll, Knockout and FCS) under two oxygen atmospheres $(20 \%$ and $5 \%$ $\mathrm{O}_{2}$ ) are presented in Table 2. The results of the ANOVA showed that there was no effect $(p>0.05)$ of macromolecule supplements of IVM medium (BSA, PVA, PVP, Ficoll, Knockout and FCS) in any of the variables studied, such as cleavage (43.0 to $74.8 \%)$ and development to morulae (16.4 to $33.8 \%$ ), blastocyst (7.7 to $52.9 \%$ ) and hatched blastocyst ( 9.6 to $48.1 \%$ ). On the other hand, oxygen tension $\left(20 \%\right.$ and $\left.5 \% \mathrm{O}_{2}\right)$ had a significant effect $(p<0.05)$ in all the variables studied. There was no interaction between macromolecular supplements of IVM medium and oxygen tension. Hence, the data for those variables were presented separately as independent variables (Tables 3 and 4).

The macromolecule supplement used during in vitro maturation did not affect $(p>0.05)$ the rates of cleavage $(51.0$ to $67.9 \%)$ and development to morulae (20.8 to $30.5 \%$ ) and hatched blastocyst (20.0 to $32.5 \%$ ) (Table 3). Blastocyst development rates were higher $(p<0.05)$ in treatments PVA $(35.6 \% \pm 6.0)$ and FCS $(38.7 \% \pm 5.9)$ when compared to Knockout $(22.7 \% \pm 5.4)$ (Table 3$)$.

Higher $(p<0.05)$ rates of cleavage and development to morulae, blastocyst and hatched blastocyst were obtained after in vitro culture in $20 \% \mathrm{O}_{2}(67.4,29.2$, 40.8 and $34.0 \%$, respectively) when compared with $5 \%$ $\mathrm{O}_{2}(52.5,21.8,18.2$ and $15.6 \%$, respectively) (Table 4).

\section{Discussion}

Oocyte nuclear maturation involves meiosis resumption (germinal vesicle breakdown-GVBD), resulting in MI, first meiotic completion, polar body emission and progression to MII stage. These steps, together with the cytoplasmic maturation, prepare oocytes for being fertilized and to acquire embryonic developmental 
Table 2 Cleavage and embryonic development to morulae, blastocyst and hatched blastocyst.

\begin{tabular}{llrccrr}
\hline $\mathrm{O}_{2}$ tension (\%) & Group & $n$ & $\begin{array}{c}\text { Cleavage } \\
(\% \text { mean } \pm \text { SEM })\end{array}$ & $\begin{array}{c}\text { Morulae } \\
(\% \text { mean } \pm \text { SEM })\end{array}$ & $\begin{array}{c}\text { Blastocyst } \\
(\% \text { mean } \pm \text { SEM })\end{array}$ & $\begin{array}{c}\text { Hatched blastocyst } \\
(\% \text { mean } \pm \text { SEM })\end{array}$ \\
\hline 20 & BSA & 86 & $59.0 \pm 6.3$ & $32.9 \pm 4.1$ & $36.4 \pm 2.5$ & $28.2 \pm 4.6$ \\
& PVA & 84 & $73.0 \pm 5.9$ & $30.3 \pm 5.2$ & $42.5 \pm 8.2$ & $36.1 \pm 9.1$ \\
& PVP & 112 & $74.8 \pm 7.7$ & $24.4 \pm 6.0$ & $43.8 \pm 8.3$ & $39.9 \pm 7.1$ \\
& Ficoll & 95 & $67.1 \pm 4.6$ & $25.3 \pm 2.6$ & $33.9 \pm 6.1$ & $28.9 \pm 6.1$ \\
& Knockout & 109 & $60.3 \pm 5.8$ & $29.5 \pm 4.2$ & $35.3 \pm 5.8$ & $25.3 \pm 7.3$ \\
5 & FCS & 95 & $70.0 \pm 3.1$ & $33.8 \pm 5.9$ & $52.9 \pm 5.9$ & $48.1 \pm 5.2$ \\
& BSA & 90 & $43.0 \pm 9.4$ & $19.4 \pm 2.6$ & $11.6 \pm 4.8$ & $10.0 \pm 5.0$ \\
& PVA & 89 & $57.3 \pm 8.5$ & $21.9 \pm 5.2$ & $25.3 \pm 6.5$ & $19.7 \pm 8.1$ \\
& PVP & 97 & $59.7 \pm 6.0$ & $26.7 \pm 9.2$ & $17.8 \pm 6.2$ & $14.3 \pm 5.7$ \\
& Ficoll & 116 & $50.9 \pm 7.9$ & $16.4 \pm 3.3$ & $20.8 \pm 8.0$ & $16.8 \pm 4.5$ \\
& Knockout & 75 & $53.2 \pm 7.1$ & $21.7 \pm 5.9$ & $7.7 \pm 2.1$ & $9.6 \pm 3.2$ \\
& FCS & 91 & $52.3 \pm 8.1$ & $26.5 \pm 2.2$ & $24.5 \pm 6.0$ & $19.5 \pm 5.3$ \\
\hline
\end{tabular}

Cleavage (48 hpi) and embryonic development to morulae (144 hpi), blastocyst (168 hpi) and hatched blastocyst (192 hpi) in bovine oocytes in vitro matured in medium supplemented with bovine serum albumin (BSA; $6 \mathrm{mg} / \mathrm{ml}$ ), polyvinyl alcohol (PVA; $6 \mathrm{mg} / \mathrm{ml}$ ), polyvinyl pyrrolidone (PVP; $6 \mathrm{mg} / \mathrm{ml})$, Ficoll $(6 \mathrm{mg} / \mathrm{ml})$, Knockout $(10 \%)$ and fetal calf serum (FCS; $10 \%$ ) and submitted to oxygen $\left(\mathrm{O}_{2}\right)$ tensions of $5 \% \mathrm{CO}_{2}$ in air $\left(20 \% \mathrm{O}_{2}\right)$ and $5 \% \mathrm{O}_{2}, 5 \% \mathrm{CO}_{2}$ and $90 \% \mathrm{~N}_{2}\left(5 \% \mathrm{O}_{2}\right)$ during maturation, fertilization and culture.

Table 3 Cleavage and embryonic development to morulae, blastocyst and hatched blastocyst in bovine oocytes in vitro matured in medium supplemented with bovine serum albumin, polyvinyl alcohol, polyvinyl pyrrolidone, Ficoll, Knockout or fetal calf serum.

\begin{tabular}{lccccc}
\hline Group & $n$ & $\begin{array}{c}\text { Cleavage } \\
(\% \text { mean } \pm \text { SEM })\end{array}$ & $\begin{array}{c}\text { Morulae } \\
(\% \text { mean } \pm \text { SEM })\end{array}$ & $\begin{array}{c}\text { Blastocyst } \\
(\% \text { mean } \pm \text { SEM })\end{array}$ & $\begin{array}{c}\text { Hatched blastocyst } \\
(\% \text { mean } \pm \text { SEM })\end{array}$ \\
\hline BSA & 176 & $51.0 \pm 5.9$ & $26.8 \pm 3.2$ & $26.5 \pm 4.7^{a, b}$ & $20.9 \pm 4.4$ \\
PVA & 173 & $65.1 \pm 5.5$ & $25.7 \pm 3.8$ & $35.6 \pm 6.0^{a}$ & $29.5 \pm 6.6$ \\
PVP & 209 & $67.9 \pm 5.3$ & $25.5 \pm 5.0$ & $32.0 \pm 6.5^{a, b}$ & $29.7 \pm 6.2$ \\
Ficoll & 211 & $59.0 \pm 5.0$ & $20.8 \pm 2.4$ & $28.0 \pm 5.1^{a, b}$ & $24.1 \pm 4.4$ \\
Knockout & 184 & $56.7 \pm 4.5$ & $25.9 \pm 3.5$ & $22.7 \pm 5.4^{b}$ & $20.0 \pm 5.5$ \\
FCS & 186 & $61.1 \pm 4.9$ & $30.5 \pm 3.5$ & $38.7 \pm 5.9^{a}$ & $32.5 \pm 5.7$ \\
\hline
\end{tabular}

Cleavage (48 hpi) and embryonic development to morulae (144 hpi), blastocyst (168 hpi) and hatched blastocyst (192 hpi) in bovine oocytes in vitro matured in medium supplemented with one of the following macromolecules: bovine serum albumin (BSA; $6 \mathrm{mg} / \mathrm{ml}$ ), polyvinyl alcohol (PVA; $6 \mathrm{mg} / \mathrm{ml})$, polyvinyl pyrrolidone (PVP; $6 \mathrm{mg} / \mathrm{ml})$, Ficoll $(6 \mathrm{mg} / \mathrm{ml})$, Knockout (10\%) and fetal calf serum (FCS; $10 \%)$.

${ }^{a, b}$ Values with different superscript letters within the same column differ $(p<0.05)$.

Table 4 Cleavage ( $48 \mathrm{hpi}$ ) and embryonic development to morulae (144 hpi), blastocyst (168 hpi) and hatched blastocyst (192 hpi) in bovine oocytes in vitro matured, fertilized and cultured under oxygen tensions of $5 \% \mathrm{CO}_{2}$ in air $\left(20 \% \mathrm{O}_{2}\right)$ and $5 \% \mathrm{O}_{2}, 5 \% \mathrm{CO}_{2}$ and $90 \% \mathrm{~N}_{2}\left(5 \% \mathrm{O}_{2}\right)$.

\begin{tabular}{lccccc}
\hline Oxygen tension $(\%)$ & $n$ & $\begin{array}{c}\text { Cleavage } \\
(\% \text { mean } \pm \text { SEM })\end{array}$ & $\begin{array}{c}\text { Morulae } \\
(\% \text { mean } \pm \text { SEM })\end{array}$ & $\begin{array}{c}\text { Blastocyst } \\
(\% \text { mean } \pm \text { SEM })\end{array}$ & $\begin{array}{c}\text { Hatched blastocyst } \\
(\% \text { mean } \pm \text { SEM })\end{array}$ \\
\hline 20 & 581 & $67.4 \pm 2.4^{a}$ & $29.2 \pm 1.9^{a}$ & $40.8 \pm 2.7^{a}$ & $34.0 \pm 2.9^{a}$ \\
5 & 558 & $52.5 \pm 3.2^{b}$ & $21.8 \pm 2.1^{b}$ & $18.2 \pm 2.5^{b}$ & $15.6 \pm 2.2^{b}$ \\
\hline
\end{tabular}

$a, b$ Values with different superscript letters within the same column differ $(p<0.05)$.

competence (Thibault et al., 1987; Sirard et al., 1989). Then, culture conditions, which included medium composition and oxygen tension, used for IVM of mammalian oocytes influence subsequent embryonic development (Rose \& Bavister, 1992; Stock et al., 1997). Currently, the medium commonly used for IVM is
TCM-199 supplemented with serum and hormones. However, several studies attempted to use defined macromolecule as supplements to replace serum in culture, thus aiming to avoid composition variations and the risk of disease transmission (Mckiernan \& Bavister, 1992; Stock et al., 1997; Krisher et al., 1999). 
For that reason, undefined (supplemented with FCS), semi-defined (BSA) and defined (PVA, PVP, Ficoll and Knockout) TCM-199 media were used for IVM of bovine oocytes under two oxygen tensions $(5 \%$ and $20 \% \mathrm{O}_{2}$ ) to assess their effects on nuclear maturation. The normal meiosis progression was evaluated as the percentage of oocytes at GVBD, MI and MII at 6, 18 and $24 \mathrm{~h}$ of IVM, respectively.

Under atmospheric oxygen concentration $\left(20 \% \mathrm{O}_{2}\right)$ the number of oocytes at GVBD stage produced in the undefined medium with FCS was higher than that in defined media with PVP, Ficoll and Knockout. This finding may be caused by meiosis acceleration promoted by FCS, as reported for blastocyst development (Mastromonaco et al., 2004). However, all macromolecule supplements were similar in $\mathrm{MI}$ and $\mathrm{MII}$ rates at $20 \% \mathrm{O}_{2}$. At a lower oxygen concentration $\left(5 \% \mathrm{O}_{2}\right)$ the defined supplements PVA, PVP and Ficoll were superior to BSA, Knockout and FCS in GVBD rates, but all treatments, except BSA, were similar in MI rates and PVP was superior in MII rates. From these results, we can observe that, for the earliest step of nuclear progression (GVBD), undefined (FCS) and semi-defined (BSA) media were more efficient at $20 \% \mathrm{O}_{2}$, while defined media (supplemented with PVA, $\mathrm{PVP}$, or Ficoll) were better at reduced oxygen tension $\left(5 \% \mathrm{O}_{2}\right)$. Thus, the oxygen concentration influenced the macromolecule supplement used for IVM, similar to the oxygen tension effects observed with culture medium (TCM-199 versus SOF; Castro e Paula \& Hansen, 2007) and with other supplements, such as glucose (Oyamada \& Fukui, 2004) and melatonin (Papis et al., 2007). The positive effects of undefined/semidefined media at $20 \% \mathrm{O}_{2}$ and of defined media at $5 \%$ $\mathrm{O}_{2}$ became less pronounced as oocytes progressed in development.

Based on the findings of nuclear maturation (MII rates), all evaluated macromolecule supplements were suitable for use in IVM of bovine oocytes at $20 \% \mathrm{O}_{2}$, but at $5 \% \mathrm{O}_{2}$ comparable results were only obtained for PVP. Then, we support the hypothesis that IVM under the most frequently used oxygen concentration, $20 \%$ $\mathrm{O}_{2}$ (Harvey, 2007), is optimal for nuclear maturation independent of the macromolecule supplement used (defined, semi-defined or undefined). These results are contrary to the described detrimental effect of atmospheric oxygen tension $\left(20 \% \mathrm{O}_{2}\right)$ during IVM on nuclear progression (Eppig \& Wigglesworth, 1995; Smitz et al., 1996). Moreover, we observed that reduced oxygen tension $\left(5 \% \mathrm{O}_{2}\right)$ during IVM was detrimental for oocyte nuclear maturation, as previously reported (Ali \& Sirard, 2002).

To assess the effects of macromolecule supplement and oxygen tension on embryonic development, oocytes were matured in IVM media supplemented with BSA, PVA, PVP, Ficoll, Knockout and FCS at $5 \%$ or
$20 \% \mathrm{O}_{2}$ and then submitted to in vitro fertilization (IVF) and culture (IVC) in the same atmospheric condition used for IVM. The zygotes were then evaluated for cleavage and development to morulae, blastocyst and hatched blastocyst stages.

Independently of macromolecule supplement and oxygen tension, the results obtained for cleavage (mean of $60.9 \%$ ) and development to morulae $(25.7 \%)$, blastocyst (29.4\%) and hatched blastocyst (24.7\%) were similar to the average results described in the literature.

All the macromolecule supplements used for IVM promoted similar rates of cleavage, morulae and hatched blastocyst. For blastocyst development, Knockout alone was inferior to IVM media supplemented with PVA or FCS, in agreement with the results that the Knockout serum replacer is not a beneficial supplement for maturation (Moore et al., 2007). Few studies have evaluated the effects of different macromolecule supplements during maturation on embryonic development. Among these, it was observed that IVM in media supplemented with BSA (Fukui et al., 2000) and PVP in bovine (Ali \& Sirard, 2002; Chung et al., 2007) and Ficoll in mouse (Kuleshova et al., 1999) produced similar results in embryonic development when compared with serum. Then serum, which is the most used supplement used for IVM, can be effectively replaced by BSA, PVA, PVP and Ficoll without detrimental effects on early embryonic development.

These results are in disagreement with the observed reduction in embryonic development when PVA (Fukui et al., 2000) was used for IVM. Also, we did not observe developmental block (Camous et al., 1984) nor reduced viability (Wright \& Bondioli, 1981) of embryos when IVM was performed in defined media.

Analysing the two atmospheric conditions employed during all IVP procedures (including IVM, IVF and IVC), independent of macromolecule supplement for IVM, we observed that utilization of atmospheric oxygen tension $\left(20 \% \mathrm{O}_{2}\right)$ resulted in higher rates of embryonic development (cleavage, morulae, blastocyst and hatched blastocyst) than a lower oxygen concentration $\left(5 \% \mathrm{O}_{2}\right)$. Therefore, these results suggest that, when adopting only one atmosphere condition for all IVP procedure, it is preferable to use $20 \% \mathrm{O}_{2}$ rather than $5 \% \mathrm{O}_{2}$.

In constrast to other reports (Yuan et al., 2003; Corrêa et al., 2008), we have obtained suitable development rates to blastocyst $(40.8 \%)$ in IVC at $20 \% \mathrm{O}_{2}$ in the absence of co-culture.

The detrimental effects observed for $5 \% \mathrm{O}_{2}$ during IVP culture may be a consequence of the utilization of this atmospheric value, especially for IVM, as lower maturation rates were obtained under this oxygen concentration. It is well established that IVM conditions affect embryonic development (Rose \& Bavister, 1992; 
Stock et al., 1997) and that an oxygen tension lower than atmospheric in IVM reduces cleavage and blastocyst development (Betterbed \& Wright, 1985; Castro e Paula \& Hansen, 2007). The superiority of a higher oxygen concentration during IVM may be provided by oxygen availability to oocyte, after its consumption by cumulus cells in cumulus-oocyte complexes (COCs; Castro e Paula \& Hansen, 2007), as described for the oxygen gradient that occurs in ovarian follicles (Gosden \& Byatt-Smith, 1986). However, better embryo development after IVM under lower oxygen tension was also reported (Hashimoto et al., 2000), which may reflect other effects of medium composition and culture conditions.

Some studies (Papis et al., 2007; Corrêa et al., 2008) assumed that higher oxygen tensions during IVC resulted in ROS production that was detrimental for embryo development. However, it was previously demonstrated that physiological concentrations of ROS may, therefore, play a key role in the process of oocyte maturation (Dalvit et al., 2005). Then, IVM culture of COCs under low oxygen concentration may have lead to oocyte hypoxia and impairment of a physiological concentration of ROS that is necessary for normal cellular growth and development (Dalvit et al., 2005).

In summary, we observed that oxygen concentration influences the macromolecule supplement used for IVM in nuclear maturation, as beneficial results especially in earlier steps of maturation were obtained for undefined (FCS) and semi-defined media (BSA) at $20 \% \mathrm{O}_{2}$ and for defined media (PVA, PVP and Ficoll) at $5 \% \mathrm{O}_{2}$. Independent of macromolecule supplement, higher nuclear maturation rates were obtained at $20 \% \mathrm{O}_{2}$ and this atmospheric oxygen tension was found to be optimal for IVM of bovine oocytes. To promote embryo development, considering macromolecule supplement and oxygen tension as independent variables, the supplements BSA, PVA, PVP and Ficoll can replace FCS for IVM of bovine oocytes, while Knockout was not a suitable macromolecular supplement for IVM. As improved results for embryonic development were achieved at atmospheric oxygen tension, when all the steps of in vitro production (IVMFC) of bovine embryos were performed using only one atmosphere condition, the choice of oxygen concentration of $20 \% \mathrm{O}_{2}$ is preferred to $5 \% \mathrm{O}_{2}$.

\section{Acknowledgements}

This work was supported by the Fundação de Amparo a Pesquisa do Estado de São Paulo (FAPESP), Brazil, Grant \#01/06137-0. V.S.D. Caiado Castro was recipient of studentship from CAPES, Brazil and L.S.S. Barretto was recipient of studentship from FAPESP, Brazil.

\section{References}

Ali, A. \& Sirard, M.A. (2002). Effect of the absence or presence of various protein supplements on further development of bovine oocyte during in vitro maturation. Biol. Reprod. 66, 901-5.

Batt, P.A., Gardner, D.K. \& Camero, A.W. (1991). Oxygen concentration and protein source affect the development of preimplantation goat embryos in vitro. Reprod. Fertil. Dev. 3, 601-7.

Bavister, B.D. (1995). Culture of preimplantation embryos: facts and artifacts. Hum. Reprod. Update 1, 91-148.

Betterbed, B. \& Wright, R.W. Jr,. (1985). Development of onecell ovine embryos in two culture media under two gas atmospheres. Theriogenology 23, 547-53.

Brackett, B.G. \& Zuelke, K.A. (1993). Analysis of factors involved in the in vitro production of bovine embryos. Theriogenology 39, 43-64.

Camous, S., Heyman, Y., Méziou, W. \& Ménézo, Y. (1984). Cleavage beyond the block stage and survival after transfer of early bovine embryos cultured with trophoblastic vesicles. J. Reprod. Fertil. 72, 479-85.

Carolan, C., Lonergan, P., Van Langenonckt, A. \& Mermillod, P. (1995). Factors affecting bovine embryo development in synthetic oviduct fluid following oocyte maturation and fertilization in vitro. Theriogenology 43, 1115-28.

Castro e Paula, L.A. \& Hansen, P.J. (2007). Interactions between oxygen tension and glucose concentration that modulate actions of heat shock on bovine oocytes during in vitro maturation. Theriogenology 68, 763-70.

Checura, C.M. \& Seidel, G.E. Jr. (2007). Effect of macromolecules in solutions for vitrification of mature bovine oocytes. Theriogenology 67, 919-30.

Chung, J.T., Tosca, L., Huang, T.H., Xu, L., Niwa, K. \& Chian, R.C. (2007). Effect of polyvinylpyrrolidone on bovine oocyte maturation in vitro and subsequent fertilization and embryonic development. Reprod. BioMed. Online 15, 198207.

Corrêa, G.A., Rumpf, R., Mundim, T.C.D., Franco, M.M. \& Dode, M.A.N. (2008). Oxygen tension during in vitro culture of bovine embryos: effect in production and expression of genes related to oxidative stress. Anim. Reprod. Sci. 104, 132-42.

Dalvit, G.C., Cetica, P.D., Pintos, L.N. \& Beconi, M.T. (2005). Reactive oxygen species in bovine embryo in vitro production. Biocell 29, 209-12.

Eppig, J.J. (1996). Coordination of nuclear and cytoplasmic oocyte maturation in eutherian mammals. Reprod. Fertil. Dev. 8, 485-9.

Eppig, J.J. \& Wigglesworth, K. (1995). Factors affecting the developmental competence of mouse oocytes grown in vitro: oxygen concentration. Mol. Reprod. Dev. 42, 44756.

Fukui, Y., Kikuchi, Y., Kondo \&, H., Mizushima, S. (2000). Fertilizability and developmental capacity of individually cultured bovine oocytes. Theriogenology 53, 155365.

Goldsborough, M.D., Tilkins, M.L., Price, P.J., Lobo-Alfonso, J., Morrison, J.R., Stevens, M.E., Meneses, J., Pedersen, R., Koller, B. \& Latour, A. (1998). Serum-free culture of murine embryonic stem (ES) cells. Focus (Gibco) 20, 8-12. 
Gosden, R.G. \& Byatt-Smith, J.G. (1986). Oxygen concentration gradient across the ovarian follicular epithelium: model, predictions and implications. Hum. Reprod. 1, 658.

Gutiérrez-Adán, A., Lonergan, P., Rizos, D., Ward, F.A., Boland, M.P, Pintado, B. \& De La Fuente, J. (2001). Effect of the in vitro culture system on the kinetics of blastocyst development and sex ratio of bovine embryos. Theriogenology 55, 1117-26.

Harvey, A.J. (2007). The role of oxygen in ruminant preimplantation embryo development and metabolism. Anim. Reprod. Sci. 98, 113-28.

Hashimoto, S., Minami, N., Takakura, R., Yamada, M., Imai, H. \& Kashima, N. (2000). Low oxygen tension during in vitro maturation is beneficial for supporting the subsequent development of bovine cumulus-oocyte complexes. Mol. Reprod. Dev. 57, 353-60.

Krisher, R.L., Lane, M. \& Bavister, B.D. (1999). Developmental competence and metabolism of bovine embryos cultured in semi-defined and defined culture media. Biol. Reprod. 60, 1345-52.

Kuleshova, L.L., Macfarlane, D.R., Trounson, A.O. \& Shaw, J.M. (1999). Sugars exert a major influence on the vitrification properties of ethylene glycol-based solutions and have low toxicity to embryos and oocytes. Cryobiology 38, 119-30.

Mass, D.H., Storey, B.T. \& Mastroianni, L. Jr. (1976). Oxygen tension in the oviduct of rhesus monkey (Macaca mulatta). Fertil. Steril. 27, 1312-17.

Mastromonaco, G.F., Semple, E., Robert, C., Rho, G.J., Betts, D.H. \& King, W.A. (2004). Different culture media requirements of IVF and nuclear transfer bovine embryos. Reprod. Domest. Anim. 39, 462-7.

McKiernan, S.H. \& Bavister, B.D. (1992). Different lots of bovine serum albumin inhibit or stimulate in vitro development of hamster embryos. In Vitro Cell. Dev. Biol. 28A, 154-6.

Moore, K., Rodriguez-Sallaberry, C.J., Kramer, J.M., Johnson, S., Wroclawska, E., Goicoa, S. \& Niasari-Naslaji, A. (2007). In vitro production of bovine embryos in medium supplemented with a serum replacer: effects on blastocyst development, cryotolerance and survival to term. Theriogenology 68, 1316-25.

Nakao, H. \& Nakatsuji, N. (1990). Effects of co-culture, medium components and gas phase on in vitro culture of in vitro matured and in vitro fertilized bovine embryos. Theriogenology 33, 591-600.

Noda, Y., Goto, Y., Umaoka, Y., Shiotani, M., Nakayama, T. \& Mori, T. (1994). Culture of human embryos in alpha modification of Eagle's medium under low oxygen tension and low illumination. Fertil. Steril. 62, 1022-7.

Orsi, N.M. \& Leese, H.J. (2004). Amino acid metabolism of preimplantation bovine embryos cultured with bovine serum albumin or polyvinyl alcohol. Theriogenology 61, 561-72.

Oyamada, T. \& Fukui, Y. (2004). Oxygen tension and medium supplements for in vitro maturation of bovine oocytes cultured individually in a chemically defined medium. J. Reprod. Dev. 50, 107-17.

Papis, K., Poleszczuk, O., Wenta-Muchalska, E. \& Modlinski, J.A. (2007). Melatonin effect on bovine embryo development in vitro in relation to oxygen concentration. J. Pineal Res. 43, 321-6.

Rose, T.A. \& Bavister, B.D. (1992). Effect of oocyte maturation medium on in vitro development of in vitro fertilized bovine embryos. Mol. Reprod. Dev. 31, 727.

Sagirkaya, H., Misirlioglu, M., Kaya, A., First, N.L., Parrish, J.J. \& Memili, E. (2007). Developmental potential of bovine oocytes cultured in different maturation and culture conditions. Anim. Reprod. Sci. 101, 225-40.

Sirard, M.A \& Blondin, P. (1996). Oocyte maturation and IVF in cattle. Anim. Reprod. Sci. 42, 417-26.

Sirard, M.A., Florman, H.M., Leibfried-Rutledge, M.L., Barnes, F.L., Sims, M.L. \& First, N.L. (1989). Timing of nuclear progression and protein synthesis necessary for meiotic maturation of bovine oocytes. Biol. Reprod. 40, 125763.

Smitz, J., Cortvrindt, R. \& Van Steirteghem, A.C. (1996). Normal oxygen atmosphere is essential for the solitary long-term culture of early preantral mouse follicles. Mol. Reprod. Dev. 45, 466-75.

Stein, A. (2007). Decreasing variability in your cell culture. Biotechniques 43, 228-9.

Stock, A.E., Woodruff, T.K. \& Smith, L.C. (1997). Effects of inhibin $\mathrm{A}$ and activin A during in vitro maturation of bovine oocytes in hormone- and serum-free medium. Biol. Reprod. $56,1559-64$.

Thibault, C., Szöllösi, D. \& Gérard, M. (1987). Mammalian oocyte maturation. Reprod. Nutr. Dev. 27, 865-96.

Thompson, J.G., Simpson, A.C., Pugh, P.A., Donnelly, P.E. \& Tervit, H.R. (1990). Effect of oxygen concentration on in-vitro development of preimplantation sheep and cattle embryos. J. Reprod. Fertil. 89, 573-578.

Voelkel, S.A. \& Hu, Y.X. (1992). Effect of gas atmosphere on the development of one cell bovine embryos in two culture systems. Theriogenology 37, 1117-31.

Webster, H.L. (1982). Colloid osmotic pressure: theoretical aspects and background. Clin. Perinatol. 9, 505-21.

Wright, R.J. Jr \& Bondioli, K.R. (1981). Aspects of in vitro fertilization and embryo culture in domestic animals. J. Anim. Sci. 53, 702-29.

Yuan, Y.Q., Van Soom, A., Coopman, F.O.J., Mintiens, K., Boerjan, M.L., Van Zeveren, A., De Kruif, A. \& Peelman, L.J. (2003). Influence of oxygen tension on apoptosis and hatching in bovine embryos cultured in vitro. Theriogenology 59, 1585-96. 